\title{
Business Models for Crowd-driven IoT Ecosystems: A Review
}

Xenia Ziouvelou* and Frank McGroarty

Southampton Business School, University of Southampton, Southampton, United Kingdom

\section{Abstract}

Today's networked society is populated by complex business ecosystems that have moved away from the centralised firm-centric structure to a more distributed, crowd-driven ecosystem structure that adopts an open participatory value creation model. Such crowd-driven ecosystems take advantage of technological advancements and underlying network effects in order to harness the collective power and intelligence of the crowd. This ability to co-create value by actively collaborating with the crowd has been fueled by the Internet of Things (IoT) introducing new user-centric paradigms, such as mobile crowd sensing (MCS), which leverage the power and the wisdom of the crowd to observe, measure, and make sense of particular phenomena by exploiting user-owned mobile and wearable devices. Crowd-driven IoT ecosystems have emerged taking advantage of technological advancements and underlying network effects in order to harness the collective power and intelligence of the crowd. However, although research in the context of business ecosystems and business models has gained substantial importance in recent years, there is still a limited understanding of the business dynamics of these emerging, technologically advanced, crowddriven ecosystems. The vast majority of existingresearch efforts place emphasis on business models in the IoT context and only a few studies consider business models for IoT ecosystems. However, one can identify a research gap in relation to business models for crowd-driven ecosystems in the IoT context. This study aims to contribute to the emerging crowd-driven IoT ecosystems literature by examining business models in such environments. For this reason both an exploratory and explanatory research approach is employed. This study provides an exploratory review analysis that synthesizes current scientific knowledge and an explanatory framework that facilitates the analysis of business model components and frameworks that correspond to the needs of firm-centric and ecosystem-centric IoT environments. The study concludes by providing suggestions for the business model development for technologically advanced, crowd-driven ecosystems as in the area of IoT based on its findings, establishing this way a solid foundation for future research in the area of crowd-driven IoT ecosystems.

\section{Introduction}

During the past few years we have been witnessing the emergence of new participatory value creation models driven by users and facilitated by technological advancements. These models and the increasing digitization of our economy have fostered the emergence of complex, technologically advanced and constantly evolving ecosystems that are driven by and for users.

Within this inter-connected business environment (networks of companies, networks of industries, networks of things, networks of people) competition has become more complex and dynamic, while partnerships (business and community partnerships) have a vital role and value, and the business boundaries are blurring. Business success in this complex and constantly evolving system is determined by the ecosystem's ability to bring together a variety of strategic business elements in order to jointly co-created shared value.

Such ecosystems are characterised by open collaborative innovation practices where users mutually collaborate by openly communicating their ideas, sharing best practices, and creating new knowledge across sectors. These online, decentralised and distributed, crowd-driven networks take advantage of underlying network effects in order to harness the collective power and intelligence of the crowd. Such novel paradigms fuel an increasing interest in mobile crowdsensing (MCS) methods in the context of Internet of Things (IoT), which leverage not only the power of physical things connected to the Internet but also the wisdom of the crowd to observe, measure, and make sense of particular phenomena by exploiting user-owned mobile and wearable devices. in the context of IoT. p.ziouvelou@soton.ac.uk org/10.15344/2456-4451/2017/121

\section{Publication History:}

Received: June 27, 2017

Accepted: November 07, 2017

Published: November 09, 2017

\section{Keywords:}

Business models, Business model ontologies, Crowd-driven ecosystems, Crowd-driven IoT ecosystems, Ecosystem business models, Ecosystem-centric IoT business models, Explanatory business model framework, IoT business models, IoT firm-centric business models advancements and underlying network effects in order to harness the collective power and intelligence of the crowd. However, one can identify a research gap in the literature addressing the emergence of generic crowd-driven ecosystems as well as crowd-driven ecosystems

Given the nature of the crowd-driven IoT ecosystems, current approaches to developing a business model fail to capture and analyze their dynamics and thus, their full potential. This necessitates the identification of analogous business model building blocks and frameworks that will describe the dynamic nature of these emerging value ecosystems. This study aims to provide a foundation for the development of these emerging business model frameworks.

The paper is structured as follow. Section 2 provides an overview of the approach that has been adopted inthis study. Section 3 examines the rise of crowd-driven IoT ecosystems and Section 4 explores the research area of business models for crowd-driven IoT ecosystems and provides an overview of existing studies and related work in this field. Section 5 provides an explanatory framework that classifies research in the context of IoT business models and frameworks aiming to "Corresponding Author: Dr. Xenia Ziouvelou, Southampton Business, Law and Art School, University of Southampton, Southampton, United Kingdom; E-mail:

Citation: Ziouvelou X, McGroarty F (2017) Business Models for Crowd-driven IoT Ecosystems: A Review. Int J Comput Softw Eng 2: 121. doi: https://doi.

Copyright: (c) 2017 Ziouvelou et al. This is an open-access article distributed under the terms of the Creative Commons Attribution License, which permits unrestricted use, distribution, and reproduction in any medium, provided the original author and source are credited. 
identify research gaps and guide future research in the area. Finally, Section 6, concludes this study and outlines future work in the area.

\section{The Study Approach}

This study aims to shed light into the emergence and challenges associated with business model in crowd-driven IoT ecosystems. For this reason both an exploratory and explanatory research approach is employed. Initially, an exploratory review analysis that synthesizes current scientific knowledge is provided. This analysis relies on two streams of literature, namely, ecosystem research [2,3] and business model research [4] aiming to reflect upon the notion of crowd-driven IoT ecosystems [1]. This is followed by a classification of existing research under an explanatory framework that facilitates the analysis of business model components and frameworks that correspond to the needs of IoT ecosystems. The study concludes by providing suggestions for the business model development for technologically advanced, crowd-driven ecosystems as in the area of IoT based on its findings, establishing this way a solid foundation for future research in the area of crowd-driven IoT ecosystems.

\section{Crowd-driven Ecosystems}

Over the past few years, the ecosystem notion has gaineda lot of research attention both inthe business and the technological literature. Ecosystems have emerged as a concept that facilitates the description and analysis of the complex interconnected networks that populate our networked society $[5,6]$. This view essentially reflects upon the change in the way value is created and captured in todaysbusiness environment; a shift from standalone companies to integrated corporate systems and eventually ecosystems and crowddriven ecosystems powered by technology, user participation and open collaborative innovation [7]. As such in the context of generic exosystems,value creation and capture are embedded within the whole ecosystem, implying that while value is co-created and cocaptured $[8,5,9,10]$. In crowd-driven ecosystems, on the other hand, value is co-created, co-captured and co-distributed presenting a new triangular participatory value model driven by and for users [1].

However, despite this fundamental change in the business logic, from firm-centric to ecosystem-centric and crowd driven ecosystemcentric [1], we see that the business model research has not evolved in parallel. Given the disruptive nature of the crowd-driven IoT ecosystems current business model approaches and frameworks, facilitating the development, analysis and implementation of business models, should be adapted accordingly under a dynamic flexible business model framework.

\section{Eco systems}

The origin of the ecosystem concept lies in the nature world and it was in 1993 that Moore [2] provided a parallel of business and natural ecosystems. The term was coined in 1935 by the British botanist Arthur Tansley, in order to denote a community of living organisms interacting with each other and their environment as a system. Biological ecosystems are the productive engines of the planet [11, $\mathrm{p}: 3]$, that evolve and are dynamic, constantly remaking themselves, reacting to natural disturbances and to the competition among and between species [11]. Direct analogies of biological ecosystems can be found both in the knowledge, industrial, business, innovation ecosystems and crowd-driven ecosystems research. However, although the natural ecosystem model presents an ideal metaphor for these ecosystem types, it also presents fundamental differences with other systems such as cultural ones [12-14].
In the industrial context, it was [15] that presented industrial ecosystems as a direct analogy of natural ecosystems. In particular, industrial ecosystems were viewed as an industrial system where all material is recycled infinitely and efficiently by changing the habits of manufacturers and consumers maintaining this way our standard of living without causing environmental devastation [15]. Industrial ecology research $[15,16]$ indicates that industrial ecosystems function in accordance with the system development principles of natural ecosystems. This sustainable development field, studies local, regional and global industrial systems, aiming to transform them from linear systems to closed-loop ones; that is finding ways that the industrial world can move closer to the ecological model and its dynamics [17].

In the business context, Moore [2] made the parallel and proposed that a company can be viewed not as a member of a single industry but as part of a business ecosystem that crosses a variety of industries (p:76). According to Moore, a business ecosystem is an economic community supported by a foundation of interacting organizations and individuals - the organisms of the business world [18], that similar to biological ecosystems, are characterized by high complexity, interdependence, cooperation, competition and coevolution ${ }^{1}[18$, $5,19]$ and they are formed both intentionally and as a result of an accident. Moore suggests that it is conscious choice that differentiates between ecological and social systems [18].This transition from standalone companies to integrated corporate systems and eventually crowd-driven ecosystems is powered by technology, user participation and the move towards open innovation [7]. Emerging crowd-driven ecosystems leverage the network effects and harness the collective intelligence of a large number of contributors. Five distinct ecosystem types are distinguished in this paper: knowledge ecosystems, business ecosystems, digital business ecosystems, innovation ecosystems and crowd-driven ecosystems. In the sections that follow, we provide a short overview of these ecosystem concepts and as well as a taxonomy following the analysis of [1] (Table 1).

Existing research indicates that geographically clustered organisational entities enjoy numerous advantages as they can benefit from their co-location, their collective resources and the dynamic knowledge interactions that occur between them [20]. Such knowledge ecosystems play a central role in increasing knowledge creation and the speed of innovation diffusion [21] through evolutionary networks of collaboration [22]. In the online context, such knowledge interactions can be found within open source communities where knowledge creation and co-creation is evident among community members that exhibit virtual proximity/co-location [23]. Although research in knowledge ecosystems has implicitly assumed that such knowledge ecosystems evolve into business ecosystems, existing studies in the area indicate that there is a disconnection between the development of each type of ecosystem as they have different value creation processes [24].

According Moore, business ecosystems are viewed as economic communities of interacting organisms of the business world [18] with many horizontal relations with a coopetition structure (both collaborative and competitive relationships) [2] aiming to jointly deliver a product or service to customers [24]. Moore indicates that such ecosystems are a composition of customers, lead producers,

${ }^{1}$ The importance of longitudinal co-evolution (a key factor of healthiness according to Moore [18]) has been moderated by Iansiti and Levien [86]. 
competitors, and other stakeholders, while the keystone species (star structure model, often hierarchical [25], are leadership companies with a strong influence [18]. On the other extreme, one can find the flat business ecosystem model, which is a composition of mainly small and medium firms as well as large ones [26]. The focus of business ecosystems is on the commercialisation of knowledge and the delivery value to the end users as an interrelated system of interdependent companies rather than as individual companies [24,27]. These nested business networks act as a source of competitive advantage for individual business entities, and depending on the ecosystems' degree of productivity, robustness and ability to create opportunities for new firms the can succeed [28].

The online environment facilitates the creation, co-evolution and expansion of such ecosystems across diverse business sectors. The diffusion of ICT (information and communication technology) and the convergence of three networks: ICT networks, social networks, and knowledge networks [29], enabled the creation of digital business ecosystems. These ecosystems are partial digital representation of a physical business ecosystem [29], that enhance cooperation, knowledge sharing and value creation among digital species; a direct metaphor of natural species in biological ecosystem theory [26]. The digital business ecosystem concept facilitates the emergence of new forms of dynamic business interactions between human and digital entities and systems and global cooperation among companies, public and private organisations, business communities and the general public fostering this way economic growth at a local and regional level.

Innovation ecosystems, on the other hand, enhances the ability of the organisations to create value and innovate at level and pace greater than their competitors. Innovation ecosystems can be physical and/ or online and virtual networks that focus on fostering creativity, as well as, triggering, developing and diffusing innovation and enabling technological development among diverse entities in an open or closed context. These ecosystems are based on successful examples of agglomeration whether in geographic, economic, industrial or entrepreneurial terms [30] and unlike business ecosystems, they lack the customer (demand) side [31]. Innovation ecosystems have emerged as a multilevel, multimodal, multinodal, and multiagent system of systems [3] where innovation, co-creation, and coinnovation occur in order to generate shared value [32].

During the past few years crowd-driven ecosystems [1] have emerged, powered by technology, open innovation, and participatory value creation processes driven by users. Crowd-driven ecosystems are virtual distributed ecosystems that facilitate the creation of a global meta-environment for realising a change in the role of the users from passive to active co-creators, collaborators and co-innovators making them partners in the innovation process. According to [1], crowd-driven ecosystems leverage the distributed network effects and harness the collective power and intelligence of the user community that massively collaborates [34] creating in such a way shared value [35]. These open, collaborative user-driven, value creation ecosystems enable individuals to collaborate by openly communicating their ideas, sharing data, best practices and creating new knowledge that enhances the innovation potential of our society. In particular, they explore the direct and indirect interactions with the user community through crowdsourcing, crowdsensing and crowdfunding processes harnessing this way the collective crowd capital from a holistic perspective.

The Internet of Things (IoT) acted as a catalyst for harnessing the capacity of the crowd, as it introduced new user-centric paradigms, such as mobile crowd sensing (MCS) [36,37]. MCS goes beyond traditional sensing techniques (e.g., sensor networks, etc.,) leveraging both the power and the wisdom of the crowd in order to sense, observe, measure and make sense of real-world conditions (e.g., environmental, etc.,) and activities (e.g., personal activities and interactions, etc.) using user-owned mobile and wearable devices. Crowd-driven IoT ecosystems [1] utilise advanced IoT technological platforms that elevate the role of people (demand-driven) for enhancing the shared

\begin{tabular}{|c|c|c|c|c|c|}
\hline & Knowledge ecosystem & $\begin{array}{l}\text { Business } \\
\text { ecosystem }\end{array}$ & $\begin{array}{l}\text { Digital Business } \\
\text { ecosystem }\end{array}$ & Innovation ecosystem & $\begin{array}{l}\text { Crowd-driven } \\
\text { ecosystem }\end{array}$ \\
\hline Function & $\begin{array}{l}\text { New knowledge } \\
\text { creation }\end{array}$ & $\begin{array}{l}\text { Customer value (knowledge } \\
\text { commercialisation) }\end{array}$ & $\begin{array}{l}\text { Customer value } \\
\text { (knowledge } \\
\text { commercialisation) }\end{array}$ & $\begin{array}{l}\text { Innovation creation/ co- } \\
\text { innovation }\end{array}$ & $\begin{array}{l}\text { Crowd-driven shared } \\
\text { value creation/co- } \\
\text { creation }\end{array}$ \\
\hline Connectivity & $\begin{array}{l}\text { Decentralised and } \\
\text { distributed }\end{array}$ & Geographically clustered & Global and distributed & $\begin{array}{l}\text { Geographically clustered } \\
\text { or Global and distributed }\end{array}$ & Global and distributed \\
\hline Mode & Physical or online & Physical & Online \& virtual & Physical, online\& virtual & Online\& virtual \\
\hline Relationships & $\begin{array}{l}\text { Synergetic and co- } \\
\text { operative }\end{array}$ & $\begin{array}{l}\text { Competitive and collaborative } \\
\text { ("co-opetion") }\end{array}$ & $\begin{array}{l}\text { Competitive and } \\
\text { collaborative ("co- } \\
\text { opetion") }\end{array}$ & $\begin{array}{l}\text { Co-operative and } \\
\text { collaborative }\end{array}$ & $\begin{array}{l}\text { Co-operative, } \\
\text { synergetic and } \\
\text { collaborative (mass } \\
\text { collaboration) }\end{array}$ \\
\hline Openness & $\begin{array}{l}\text { High degree of } \\
\text { openness or closed }\end{array}$ & Various degrees of openness & $\begin{array}{l}\text { Various degrees of } \\
\text { openness }\end{array}$ & $\begin{array}{l}\text { High degree of openness } \\
\text { or closed }\end{array}$ & $\begin{array}{l}\text { High degree of } \\
\text { openness }\end{array}$ \\
\hline Structure & $\begin{array}{l}\text { Dynamic inter- } \\
\text { organisational, inter- } \\
\text { personal }\end{array}$ & $\begin{array}{l}\text { Dynamic or static, and inter- } \\
\text { organisational }\end{array}$ & $\begin{array}{l}\text { Dynamic or static, and } \\
\text { inter-organisational }\end{array}$ & $\begin{array}{l}\text { Dynamic inter- } \\
\text { organisational and inter- } \\
\text { personal }\end{array}$ & Dynamic, complex \\
\hline Key actors & $\begin{array}{l}\text { University, research } \\
\text { organisation/ institute }\end{array}$ & Large company & Large company & $\begin{array}{l}\text { Large company or } \\
\text { community }\end{array}$ & $\begin{array}{l}\text { NGO/Non-profit } \\
\text { initiative or } \\
\text { community or } \\
\text { company }\end{array}$ \\
\hline
\end{tabular}

Table 1. Taxonomy of the different types of ecosystems (extending [1]) 
value co-creation that occurs between the open cooperation of four distinct stakeholder segments: academia, government, industry and civil society (user, citizen, customer) (quadruple helix model [38], which extends the triple helix by adding the user as the fourth helix (see Figure 1)). As such, although these actors work together in order to co-create value far beyond the scope of what any single entity could do alone, these ecosystems are crowd-driven suggesting that the role of within these IoT environments that leverage its power and wisdom.

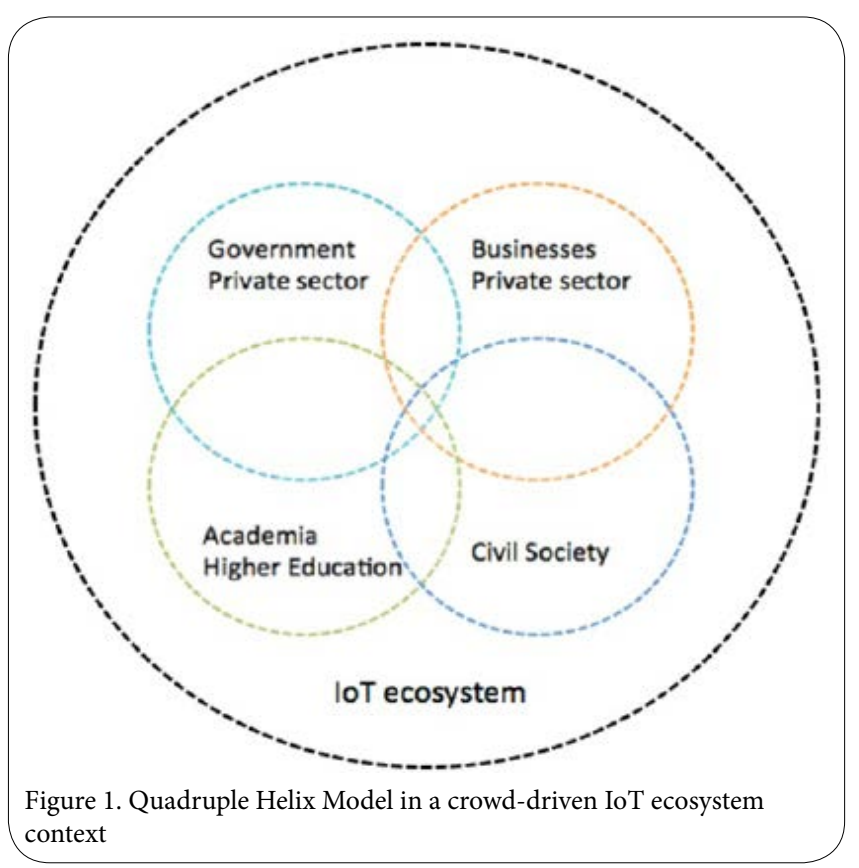

Crowd-driven IoT ecosystems can exist in many forms, concentrating on specific crowd-driven functions such as crowdsourcing, crowdsensing and crowdfunding, among others, or, increasingly, they can be hybrid; not tied to a specific mode [1]. To date a number of crowdsourcing ecosystems exist, such as mobile ones as in the case of OpenStreetMap (crowdsourced map of the world), Waze (crowd-driven traffic navigation); web-based ones such as Amazon Mechanical Turk. Similarly, numerous crowdsensing ecosystems can be found such as Phone Lab (open access smart phone testbed), Ushahidi (user geo-location data) and APISENSE (crowdsensing for experimental datasets) among others that monitor a range of variables such as city noise [39] climate [40] and emergencies [41].

In the context of crowd-driven IoT ecosystems, one can identify a few that integrate both crowdsourcing and crowdsensing perspectives. Some examples of such distributed hybrid crowd-driven IoT ecosystems include mCrowd (crowdsourcing and participatory sensing) and EpiCollect (crowdsourcing and crowdsensing for survey purposes) [1]. However these ecosystems cover only partially crowdsourcing and crowdsensing elements and they do not facilitate the integration of existing physical IoT testbeds and existing FIRE testbeds with any crowd-driven resources such as smart phones. To our knowledge, the only crowd-driven IoT ecosystem that integrates both crowd sourcing and crowd sensing (opportunistic and participatory sensing) elements and crowd funding to a certain degree, while it assimilates smart phones with existing testbeds, is IoT Lab [1].

However, when business models for such crowd-driven IoT ecosystems are examined, a gap is found in the existing research. Prevailing studies in the area place emphasis principally up on the the crowd/user is bigger and highly critical as it acts as the driving force

technical aspects of crowd-driven IoT ecosystems mainly related to their development and only recently technical and non-technical elements for the design of such ecosystems were considered [1]. Hence, there is a need for a systematic analysis of business models for such emerging ecosystems and analogous business model frameworks that will address the needs of such crowd-driven ecosystems.

\section{Business Models for Crowd-driven IoT Ecosystems: A Literature Review}

The business model concept is a relatively recent one. Although it first appeared in an academic article in 1957 [42] and in the title of an academic paper in 1960 [43], it was during the 1990's that it started to gain widespread popularity. The advent of the Internet and the changing firm boundaries enhanced further the interest in the notion of business models and played a critical role for its enhancement [44, 45].

Since then, the business model construct has received a lot of research attention providing numerous definitions, taxonomies, typologies and business model components among others [45-50]. However, this research stream reflects numerous fundamental differences rather than similarities, which to some extent may be attributed to the different perspectives (organisational, social, economic, strategic, etc.) and research areas (i.e., technology, e-business, m-business, etc.) [51]. To date there is still a lack of consensus over the Business Model concept and components. For the purposes of this study, we extend the firm-centric definition of Magretta [46]] and we define a crowd-driven ecosystem business model as a story that explains how a crowd-driven ecosystem works, essentially a story that explains how a crowd-driven ecosystem, co-creates, co-captures and co-distributes value for its participants.

\section{From firm-centric business models to ecosystem-centric business models}

Over the years, the business model concept has evolved from a general construct that explains how a firm interacts with suppliers, customers and partners [47] and how it creates and distributes value in a profitable manner [52] to an innovative business logic that disrupts entire industries, creating substantial value for the customers and corporate stakeholders and competitive advantages for the company itself. This aligns perfectly with two key realisations, firstly that product and process innovation alone are no longer sufficient for companies to stay competitive in today's fast-moving, networked economy [53]. Innovative business models are a critical component of business success as they innovate upon the core corporate logic of value creation and value capture. The advancements in information technology and the increased digitisation have fostered the emergence of numerous innovative business models such as platform-based business models $[54,55]$ where value is created by linking markets from different sides of its network, open business models[56-58] that create value by integrating ideas, knowledge, and resources from external partners into the business model of a single organisation.

Secondly that our networked society is populated by complex business ecosystems that move away from centralised firm-centric structures to more ecosystem-centric structures [59-61]. Business model research is populated by firm-centric business models studies that view the business model as a "blueprint of how a single company does business [48]. This logic however is challenged by today's inter-connected business environment. Our network economy 
necessitates that emphasis is placed upon ecosystems rather than on single firms. Consequently, the level of analysis in business model research should reflect this parameter and examine ecosystem-centric business models (BM2.0) that are community-driven (crowd-driven ecosystems, BM3.0) rather than firm-centric (BM1.0) ones. Existing literature points out this need for a network view on business models [59-61], since existing business models tools and frameworks address the modeling needs of single organisations rather than ecosystems.

In the context of the IoT, we see ecosystems that utilise a common set of core assets related to the interconnection of the physical world of things with the virtual world of Internet [25]. Although the business model literature has only recently started to address business modeling in such complex environments $[62,9,63]$ one can find no study examining business models in a crowd-driven IoT ecosystem context.

\section{Towards Defining a Business Model Framework for Crowd- driven ecosystems}

In an attempt to explore the research area of business models for crowd-driven IoT ecosystems and identify the research challenges it entails, we performed an exploratory study of the diverse IoT business models literature. Through the identification of the most common research patterns among the various contributions (utilising a structured approach to determine the source material that entailed the examination of numerous interdisciplinary databases and leading journals), that resulted from reviewing most cited research studies included in books, papers and articles that discussed IoT, we were able to construct an explanatory framework that classifies research on IoT business models into the following three research sub-domains:

\section{Analytical Context}

Analytical Context: This domain focuses upon the context of each research examining an IoT business context (firm-centric analysis) or an IoT ecosystem context (ecosystem-centric analysis). Firm-centric level of analysis constitutes a strong focus of research especially in the earlier stages of research in the area. Based on our analysis, 16 out of the 21 research contributions reviewed in Table 2 examine business models in an IoT business context. An interesting observation is that the ecosystem-centric analyses populate mainly the latter stages of research in the area validating this way the aforementioned shift from centralised firm-centric BM structures to more ecosystem-centric ones.

\begin{tabular}{|c|c|c|c|c|c|c|c|}
\hline \multirow[t]{3}{*}{ Year } & \multirow[t]{3}{*}{ Authors } & \multicolumn{2}{|c|}{ Analytical Context } & \multirow{3}{*}{$\begin{array}{l}\text { Descriptive } \\
\text { Analysis }\end{array}$} & \multicolumn{3}{|c|}{ Ontological Analysis } \\
\hline & & \multirow[t]{2}{*}{$\begin{array}{l}\text { IoT business } \\
\text { (firm-centric) }\end{array}$} & \multirow[t]{2}{*}{$\begin{array}{c}\text { IoT ecosystem } \\
\text { (ecosystem-centric) }\end{array}$} & & \multirow{2}{*}{$\begin{array}{l}\text { New Business } \\
\text { Model (BM) } \\
\text { Framework }\end{array}$} & \multicolumn{2}{|c|}{$\begin{array}{l}\text { Existing Business Model } \\
\text { (BM) Framework }\end{array}$} \\
\hline & & & & & & $\begin{array}{l}\text { Other BM } \\
\text { Framework }\end{array}$ & BM Canvas \\
\hline 2017 & Bilgeri and Wortmann [70] & $\mathrm{x}$ & & $\mathrm{X}$ & & & \\
\hline \multirow[t]{4}{*}{2016} & Ju, Kim and Ahn [71] & $\mathrm{x}$ & & $\mathrm{X}$ & & & $\mathrm{X}$ \\
\hline & Weinberger, Bilgeri, and Fleisch [72] & $\mathrm{x}$ & & $\mathrm{X}$ & & & \\
\hline & Schladofsky et.al. [62] & & $\mathrm{X}$ & $\mathrm{X}$ & & & $\mathrm{x}$ \\
\hline & Iivari et al. [9] & & $\mathrm{x}$ & $\mathrm{x}$ & $\mathrm{x}$ & & \\
\hline \multirow[t]{4}{*}{2015} & Dijkman et. al., [64] & $\mathrm{X}$ & & $\mathrm{X}$ & & & $\mathrm{X}$ \\
\hline & Chan [68] & $\mathrm{x}$ & & & & $\mathrm{X}^{*}$ & \\
\hline & Rong, et al. [63] & & $\mathrm{X}$ & & $\mathrm{X}$ & & \\
\hline & Fleisch, et al., [65] & $\mathrm{x}$ & & $\mathrm{X}$ & & & \\
\hline \multirow[t]{6}{*}{2014} & Turber et. al., [73] & & $\mathrm{X}$ & & $\mathrm{X}$ & & \\
\hline & Hui [66] & $\mathrm{x}$ & & $\mathrm{X}$ & & & \\
\hline & Westerlund et al., [74] & & $\mathrm{X}$ & & $\mathrm{X}$ & & \\
\hline & Qin and Yu [75] & $\mathrm{x}$ & & $\mathrm{X}$ & & & \\
\hline & $\begin{array}{l}\text { Fleisch, Weinberger and } \\
\text { Wortmann[76] }\end{array}$ & $\mathrm{X}$ & & $\mathrm{X}$ & & & \\
\hline & Silva and Maló [67] & $\mathrm{X}$ & & $\mathrm{X}$ & & & $\mathrm{X}$ \\
\hline 2013 & $\mathrm{Li}$ and $\mathrm{Xu}[77]$ & $\mathrm{x}$ & & $\mathrm{X}$ & & & $\mathrm{X}^{*}$ \\
\hline \multirow[t]{2}{*}{2012} & Sun, Yan, Lu, Bie, and Thomas [78] & $\mathrm{X}$ & & & & & $\mathrm{X}^{*}$ \\
\hline & Leminen et al., [79] & & $\mathrm{x}$ & $\mathrm{X}$ & $\mathrm{x}$ & & \\
\hline \multirow[t]{2}{*}{2011} & Bucherer and Uckelmann [80] & $\mathrm{x}$ & & $\mathrm{X}$ & & & $\mathrm{x}$ \\
\hline & Fan and Zhou [81] & $\mathrm{x}$ & & $\mathrm{X}$ & & & $\mathrm{X}^{*}$ \\
\hline 2010 & Liu and Jia [82] & $\mathrm{X}$ & & $\mathrm{X}$ & & & $\mathrm{X}^{*}$ \\
\hline \multicolumn{4}{|c|}{ Notes: } & lise a modified & sion of existing & 1siness Model & Framework \\
\hline
\end{tabular}




\section{Primary IoT business model analysis}

Research in this area focuses upon descriptive analysis of IoT business models providing definitions of the term, its function and its relationship with other components such as innovation. This research stream is key one in almost all the studies that we examined. As it can be seen in Table 2, 16 out of the 21 research contributions provide a descriptive analysis of IoT Business Models.

\section{Secondary IoT business model analysis}

Research in this area decomposes further the IoT business model concept into key components and building blocks and provides ontological analyses. This analytical stream examines the extent to which existing research utilises existing business model frameworks, such as the Business Model Canvas [69] or other business model frameworks, or new ones. As such this domain provides an indication of the maturity of the research in this area, given the fact that descriptive research provides the initial analytical basis that progressively moves towards ontological research, which constitutes an intermediate level of analysis that provides conceptual IoT business models (ontologies). These ontologies are either new or utilising existing widely adopted business model frameworks (as is or in slightly modified versions).

Based on our analysis, we can see that 15 out of the 21 contributions undertake an ontological analysis, making this domain the one with the highest ranking. In addition 6 out of the 15 propose a new business model framework. An interesting observation is that there seems to be a positive correlation between the ecosystem-centric studies (subdomain 1) and the new IoT business model frameworks (6 out of 7) potential due to the fact that an ecosystemic-analytical perspective strongly impacts upon the essence of the business model ontology. As such these studies can not utilise existing, widely adopted firm-centric frameworks. In addition, as it can be seen in Table 2, the vast majority of firm-centric studies adopt existing business model analytical frameworks (9 out of 14) such as the business model canvas ( 8 out of 9 ).

Table 2, provides a high-level overview of existing research in the area of IoT business models. In particular, it depicts the degree to which each of the 21 contributions in this literature stream address the three explanatory business model analytical sub-domains. This explanatory framework, illustrates that over the past few years research in the area of IoT business models has started to increase, aligning to the business logic shift that moved away from centralised firm-centric structures to more distributed ecosystem structures. It also becomes evident that, this new ecosystemic view necessitates new business model frameworks and approaches, the majority of the ecosystemcentric studies propose a new IoT business model framework and rarely utilise an existing one. This comes into direct contrast with the vast majority of firm-centric IoT business model studies that utilize existing frameworks and specifically the business model canvas tool. These findings indicate that research in the area of IoT ecosystem business models necessitates additional analysis in order to enhance our understanding regarding these emerging business model patterns and provide empirical validation for the proposed models.

\section{Business models frameworks}

In order to analyse further the business model elements of IoT ecosystems, as those have been proposed by the various contributions in the area, we present a taxonomy that aims to provide an overview and illustrate the commonalities of existing research studies (see Table 3). Our taxonomy is anchored upon two key pillars: (a) the analytical IoT business model perspective of the research studies: for the purposes of our analysis only ecosystem-centric IoT business model studies have been examined, and (b) the business model elements that each of the proposed IoT business model frameworks entails.

\begin{tabular}{|c|c|c|c|c|c|c|}
\hline Analytical & \multicolumn{6}{|c|}{ Ecosystem-centric IoT Business Models } \\
\hline $\begin{array}{l}\text { Ontological } \\
\text { Analysis }\end{array}$ & \multirow{2}{*}{$\begin{array}{l}\text { Existing Business Model (BM) } \\
\text { Framework - BM Canvas } \\
\text { Schladofsky et.al. (2016) [62] }\end{array}$} & \multicolumn{5}{|c|}{$\begin{array}{c}\text { New Business Model (BM) } \\
\text { Framework }\end{array}$} \\
\hline Authors & & $\begin{array}{l}\text { Iivari et al. (2016) } \\
\text { [9] }\end{array}$ & $\begin{array}{l}\text { Rong et al., } \\
\text { (2015) [63] }\end{array}$ & $\begin{array}{l}\text { Westerlund et } \\
\text { al., (2014) [74] }\end{array}$ & $\begin{array}{l}\text { Turber et. al., } \\
\text { (2014) [73] }\end{array}$ & $\begin{array}{l}\text { Leminen et al., } \\
\text { (2012) [79] }\end{array}$ \\
\hline \multirow[t]{14}{*}{ BM elements } & Value proposition & & & & Where & \\
\hline & Customer relationships & & & & Who & Customers \\
\hline & Customer segments & & & & & \\
\hline & Channels & & Capacity & & & \\
\hline & Key partners & & Cooperation & & Who & \\
\hline & Key activities & & & & & \\
\hline & Key resources & & Construct & & & \\
\hline & Cost structure & & & & & \\
\hline & Revenue streams & & & & Why & \\
\hline & & Value Co-creation & & $\begin{array}{l}\text { Value Drivers, } \\
\text { Value Nodes, } \\
\text { Value exchanges }\end{array}$ & & \\
\hline & & Value Co-capture & & Value Extract & & \\
\hline & & & Context & Value design & & Ecosystem \\
\hline & & & Configuration & & & \\
\hline & & & Change & & & \\
\hline
\end{tabular}

Table 3.Taxonomy of IoT ecosystem-centric Business model Frameworks (extending [83]) 
In accordance with our preceding analysis the most cited and widely adopted business model framework for describing business models in an IoT firm-centric environment, is the business model canvas [69]. Although this framework has been developed for a generic business model analysis, IoT business model research, adopts it either as is $[71,62,64,67]$ or with some modifications $[77,81,82]$ for the IoT context.

However, when business model frameworks for IoT ecosystems are considered one can observe an emphasis upon the introduction of distinct models that do not present any direct alignment either between them or with firm-centric business model frameworks, such as the BM canvas. This indicates a need for new business model frameworks and components that reflect the dynamic nature of the IoT domain.Only 1 out of 6 IoT ecosystem studies adopts the business model canvas [62], the rest propose new business model frameworks that adopt two distinct research paths. Specifically, 2 out of the 5 studies focus on the notion of value in IoT ecosystems placing emphasis upon value creation and value capture [9,74] as well as value design [74]. In particular, Iivari, et al. [9] propose value-driven business model framework for understanding the dynamics of an IoT ecosystems, which focuses upon value co-creation and co-capture. Given the study emphasis on Industrial Internet they also set the dimensions of scale and scope of value co-creation and co-capture.

Westerlund, et al. [74] focus upon the value flows of the IoT ecosystemic environment and propose five value pillars, namely: (1) value drivers (individual and shared motivations of the ecosystem participants), (2) value nodes(the actors, activities, and/or processes that create value), (3) value exchanges (the exchange of value by different means, resources, knowledge, and information), (4) value extract [the part of the ecosystem that extracts value (i.e., the monetisable value and the relevant nodes and exchanges needed for value creation and capture)] and (5) value design [the way (how) that value is deliberately created and captured in an ecosystem (i.e., the overall architecture of the ecosystem business model)].

The rest of the studies develop distinct frameworks that adopt the ecosystemic perspective and integrate only a few components that exist in the business model canvas (a 6C framework [63], a 3-D business model framework [73], a 2 dimensional model [79]). In particular, Rong, et al. [63] develop a 6C framework that is based on the original $3 \mathrm{C}$ framework $[84,85]$ to analyze network system in general. The $6 \mathrm{C}$ framework considers the following dimensions: (a) context (different stages/lifecycle phases of the business ecosystem have different missions, drivers and barriers), (b) cooperation (the mechanisms that partners interact in order to reach common strategic objectives), (c) construct (ecosystem structure and infrastructure), (d) configuration (ecosystem pattern and external relationship), (e) capacity (the key success features of the IoT ecosystem such as communication and accessibility, integration and synergy, learning ability, adaption and mobility), and (f) change (the pattern renewal and evolution of the IoT ecosystem).

Turber, et al. [73] propose a network-centric, 3-D business model framework with three dimensions: (1) who (the collaborating partners that build the value network), (2) where (the sources of value co-creation) and (3) why (the benefits for partners from collaborating within the value network). Leminen, et al. [79] present a twodimensional business model framework that is based on: (a) ecosystem (closed private vs. open networked) and (b) customers (business vs. consumer), based on which four distinct IoT business models are identified. Leminen et al [79] propose a two-dimensional business model framework that is based on: (a) ecosystem (closed private vs. open networked) and (b) customers (business vs. consumer), based on which four distinct IoT business models are identified.

These findings indicate that as we move away from centralised firm-centric IoT structures into ecosystem-centric ones,there is a significant need for new or updated modeling frameworks that will facilitate the analysis of such complex environments. However, existing research in the area is still at its infancy and the concept and components of ecosystemic IoT business models needs to be clarified further (see Table 2 and Table 3). In addition, new business model frameworks that acknowledge this ongoing paradigm shifts towards ecosystem thinking should be provided given the fact that to date no widely accepted framework for these environments exists. The existing research body will provide the grounds for the introduction of innovative ontologies for designing ecosystem business models in the IoT context.

In addition, as it can be seen in our preceding analysis, there is currently no study addressing business models in crowd-driven IoT ecosystems. As such we expect that future research in the area will fill in this research gap and introduce specialised frameworks that align with the needs of these emerging ecosystems.

\section{Conclusions}

The study contributes to the emerging research on crowd-driven IoT ecosystems [1]. As such, it can be seen as a first explorative step towards a better understanding of business models for crowd-driven IoT ecosystems. Aiming to contribute to this emerging research field, this study examined the rise of crowd-driven IoT ecosystems explored the notion of business models for crowd-driven IoT ecosystems while providing an overview of existing studies in this field. In addition, it provided an exploratory review analysis of current scientific knowledge in the context of IoT business models as well as an explanatory framework that facilitated the analysis of business model components and frameworks for IoT ecosystems.

The findings of this study indicate that the IoT business model domain presents some signs of maturity. As such IoT business model research is slowly moving beyond the initial stages (i.e., descriptive research studies that provide the initial analytical basis) to more indepth ontological studies, which constitutes an intermediate level of analysis that provides conceptual IoT business models. These ontologies are either new or utilising existing widely adopted business model frameworks, such as the business model canvas [69].

However, although the IoT business model field is starting to evolve from firm-centric (IoT-BM1.0 - $1^{\text {st }}$ era) to ecosystem-centric business models (IoT-BM2.0 $-2^{\text {nd }}$ era) aligning with the emerging business logic of an hyper-connected business environment, there is no research to date addressing crowd-driven ecosystem-centric business models (IoT-BM3.0 - $3^{\text {rd }}$ era).Consequently, future research is expected to shed light deeper upon ecosystem-centric business models as well as to provide some initial business model analysis in the context of crowd-driven IoT ecosystems. The unique nature of crowddriven IoT ecosystems will require the identification of analogous business model building blocks that describe the key elements of these emerging ecosystems. This perspective aligns with our findings in relation to the ecosystem-centric studies, that in their vast majority propose new IoT business model frameworks, attributed to the fact 
that this ecosystemic-analytical perspective strongly impacts upon the essence of the business model ontology. As such these studies cannot utilise existing, firm-centric frameworks but rather propose novel ones.

Moreover, this study explanatory framework that facilitates the analysis of IoT business model components and frameworks that correspond to the needs of IoT firm-centric and ecosystem-centric environments. The background knowledge that has been provided enabled us to identify research gaps in relation to business models for crowd-driven ecosystems in the IoT context. More specifically, this framework acts an on-going classification mechanism for existing research in the area, providing this way a solid foundation for future research in the area of IoT business models and crowd-driven IoT business models in particular.

The results of this study should be assessed in the light of their limitations. One general limitation of this research is that given its nature it is limited by the number and selection of previously published research and the availability of these studies. As such ongoing research in this emerging research area will be requiredso as to synthesise current scientific knowledge, enhance our understanding further as well as the validity of this research and the proposed explanatory research framework. Future research could examine holistic business model frameworks that will facilitate the analysis of the dynamic crowd-driven IoT ecosystems.

\section{Conflict of Interest}

No authors have a conflict of interest or any financial tie to disclose.

\section{References}

1. Ziouvelou $X$, Alexandrou $P$, Angelopoulos $C M$, Evangelatos $O$, Fernandes $\mathrm{J}$, et al. (2017) Crowd-Driven IoT/loE Ecosystems: A Multidimensional Approach. In Beyond the Internet of Things (pp. 341-375), Springer International Publishing.

2. Moore J F (1993) Predators and prey: A new ecology of competition Harvard Business Review: 75-86.

3. Carayannis E G (2010) Innovation, Technology, and Knowledge Management. Springer, New York.

4. Amit R and Zott C (2015) Crafting business architecture: The antecedents of business model design,Strategic Entrepreneurship Journal 9: 331-350.

5. Lehto I, Hermes J, Ahokangas P, Myllykoski J (2014) Collaboration in cloud businesses - Value networks and ecosystems. Communications of the Cloud Software.

6. Durst S, Poutanen P (2013) Success factors of innovation ecosystems Initial Insights from a literature review. In: Smeds R and Irrmann O (Eds) CO-CREATE 2013: The Boundary Crossing Conference on Co-Design in Innovation: 27-38. Aalto University Publication series SCIENCE + TECHNOLOGY.

7. Chesbrough H W, Appleyard M M (2007) Open Innovation and Strategy California Management Review 50: 57-76

8. Le TT, Tafardar M (2009) Business ecosystem perspective on value cocreation in the Web 2.0 era: implications for entrepreneurial opportunities. Int. Journal of Entrepreneurial Venturing, 1: 112-130.

9. livari MM, Ahokangas $\mathrm{P}$, Komi M, Tihinen M, Valtanen K, et al. (2016) Toward Ecosystemic Business Models in the Context of Industrial Internet. Journal of Business Models 4: 42-59.

10. Letaifa SB (2014) The uneasy transition from supply chains to ecosystems - The value- creation/value-capture dilemma. Management Decision 52 278-295.

11. World Resources Institute, 2000. World Resources 2000-2001: People and ecosystems: The fraying web of life. Report Series. $41 \mathrm{p}$.

12. Norton B, Costanza R, Bishop R C (1997) The evolution of preferencesWhy 'sovereign' preferences may not lead to sustainable policies and what to do about it. Ecological Economics, 24: 193-211.
13. Ring I (1997) Evolutionary strategies in environmental policy. Ecological Economics, 23: 237-250.

14. Ayres RU (2004) On the life cycle metaphor: where ecology and economics diverge. Ecological Economics, 48: 425-438.

15. Frosch D, Gallopoulos N (1989) Strategies for manufacturing, Scientific American, 261: 94-102.

16. Graedel T E Allenby B R (1995) Industrial Ecology. AT\& T, Prentice Hall, NJ, 412.

17. Lowe EA, Laurence KE (1995) Industrial ecology and industrial ecosystems Journal of cleaner production 3: 47-53

18. Moore JE (1996) The Death of Competition: Leadership \& Strategy in the Age of Business Ecosystems. New York: HarperBusiness

19. Jansson N, Ahokangas P, livari M, Perälä-Heape M, Salo S, et al. (2014) The competitive advantage of an ecosystemic business model: The Case of OuluHealth. Interdisciplinary Studies Journal, 3: 282-294.

20. AlmeidaP, Kogut B (1999) Localization of knowledge and the mobility of engineers in regional networks. Management Science. 45: 905-917.

21. Baptista R (1998) Clusters, innovation and growth: a survey of the literature. In: G. M. P. Swann, M. Prevezer and D. Stout, eds. The dynamics of industrial clusters: international comparisons in computing and biotechnology. Oxford: Oxford University Press: 13-51.

22. McMaster, T, Wastell, D, Ferneley, E, DeGross, J (2007) Organizational Dynamics of Technology-Based Innovation: Diversifying the Research Agenda. (Boston: Springer)235 : 457-462

23. Coughlan $\mathrm{T}$ (2014) Enhancing innovation through virtual proximity. Technology Innovation Management Review.

24. Clarysse B, Wright M, Bruneel J, Mahajan A (2014) Creating value in ecosystems: Crossing the chasm between knowledge and business ecosystems. Research Policy, 43: 1164-1176.

25. Mazhelis O, Luoma E, Warma H (2012) Defining an Internet-of-Things Ecosystem. In S. Andreev, S. Balandin, and Y. Koucheryavy (Eds.). Internet of Things, Smart Spaces, and Next Generation Networking -Lecture Notes in Computer Science 7469: 1-14.

26. Corallo A, Passiante G, Prencipe A (2007) Digital Business Ecosystems Edward Elgar Publishing, Cheltenham.

27. Valkokari K (2015) Business, innovation, and knowledge ecosystems: how they differ and how to survive and thrive within them. Technology Innovation Management Review.

28. Iansiti M and Levien R (2004) The Keystone Advantage: What the New Dynamics of Business Ecosystems Mean for Strategy, Innovation, and Sustainability. Harvard Business Press.

29. Nachira F, Nicolai A, Dini P, Louarn ML, Leon LR (2007) Digital business ecosystems

30. Andersen J B (2011) What Are Innovation Ecosystems and How To Build and Use Them. Innovation Management.

31. Wright M (2014) Academic entrepreneurship technology transfer and society: Where next? Journal of Technology Transfer, 39: 322.

32. Lee SM, Olson DL, Trimi S (2012) Co-Innovation: Convergenomics, Collaboration, and Co-Creation for Organizational Values. Management Decision, 50: 817-831.

33. Almirall E Wareham J (2008) Living labs and open innovation: Roles and applicability. eJOV: The Electronic Journal for Virtual Organization \& Networks, 10.

34. Tapscott D Williams AD (2008) Wikinomics: How mass collaboration changes everything. Penguin.

35. Porter ME, Kramer MR (2011) Creating Shared Value. Harvard Business Review

36. Burkel JA, Estrin D, Hansen M (2006) Participatory sensing, Proc. International Conference WSW'06, pp. 117-134

37. Carayannis EG, Campbell DFJ (2010) Triple Helix, Quadruple Helix and Quintuple Helix and How Do Knowledge, Innovation and the Environment Relate To Each Other? A Proposed Framework for a Trans-disciplinary Analysis of Sustainable Development and Social Ecology. International Journal of Social Ecology and Sustainable Development 1: 41-69.

38. Rana RK, Chou CT, Kanhere SS, Bulusu N, Hu W, et al. (2010) Ear-Phone an End-to-End Participatory Urban Noise Mapping System. In Proceedings of the 9th ACM/IEEE International Conference on Information Processing in Sensor Networks, Stockholm, Swede 105-116. 
Citation: Ziouvelou X, McGroarty F (2017) Business Models for Crowd-driven IoT Ecosystems: A Review. Int J Comput Softw Eng 2: 121. doi: https://doi. org/10.15344/2456-4451/2017/121

Page 9 of 9

39. Thepvilojanapong N, Ono T, Tobe Y (2010) Deployment of Fine-Grained Sensor Network and Empirical Analysis of Urban Temperature. Sensors 10: 2217-2241.

40. Ludwig T, Siebigteroth T, Pipek V (2014) CrowdMonitor: Monitoring Physical and Digital Activities of Citizens During Emergencies. Social Informatics 8852: 421-428.

41. Bellman R, Clark CE, Malcolm DG, Craft CJ, Ricciardi FM, et al. (1957) On the construction of a multi-stage, multi-person business game, Operations Research 5: 469-503.

42. Jones GM (1960) Educators, electrons, and business models: a problem in synthesis. The Accounting Review 35: 619-626.

43. Afuah A (2003) Redefining firm boundaries in the face of the Internet: Are firms really shrinking? Academy of Management Review 28: 34-53.

44. Afuah A, Tucci CL (2000) Internet business models and strategies: Text and cases. McGraw-Hill Higher Education.

45. Magretta J (2002) Why Business Models Matter. Harvard Business Review 80: 86-92.

46. Zott C, Amit R (2003) Business model design and the performance of entrepreneurial firms. Working Paper INSEAD: Fontainebleau France 18 181-199

47. Osterwalder A, Pigneur Y, Tucci C (2005) Clarifying business models: Origins, present and future of the concept. Communications of AIS 16: 1-40

48. Johnson MW, Christensen CM, Kagermann H (2008) Reinventing your business model. Harvard Business Review, 86: 50-59.

49. Osterwalder A, Pigneur $Y$ (2010) Business model generation: a handbook for visionaries, game changers, and challengers. John Wiley \& Sons.

50. Shafer SM, Smith HJ, Linder JC (2005) The power of business models. Business horizons 48: 199-207

51. Baden-Fuller C, Morgan MS (2010) Business models as models. Long range planning, 43:156-171.

52. Massa L, Tucci CL (2014). Business Model Innovation. In: Dodgson M, Gann DM, and Phillips N (eds), The Oxford Handbook of Innovation Management, Oxford, UK: Oxford University Press: 420-441.

53. Brousseau E, Penard T (2007) The Economics of Digital Business Models A Framework for Analyzing the Economics of Platforms. Review of Network Economics, 6: 81-114.

54. GawerA, CusumanoMA (2008) How companies become platform leaders MIT Sloan Management Review 49: 28-35.

55. Chesbrough HW (2006) Open Business Models: How to Thrive in the New Innovation Landscape. Boston, MA: Harvard Business School Press.

56. Chesbrough HW (2007) Why Companies Should Have Open Business Models. MIT Sloan Management Review 48: 22-28.

57. Purdy M, Robinson MC, Wei K (2012) Three new business models for "the open firm." Strategy \& Leadership 40: 36-41.

58. Carbone P (2009) The Emerging Promise of Business Ecosystems. Open Source Business Resource 11-16.

59. Muegge S (2011) Business Ecosystems as Institutions of Participation A Systems Perspective on Community-Developed Platforms. Technology Innovation Management Review 1: 4-13.

60. Muegge S (2013) Platforms, Communities, and Business Ecosystems: Lessons Learned About Technology Entrepreneurship in an Interconnected World. Technology Innovation Management Review, 3: 5-15.

61. Schladofsky W, Mitic J, Megner AP, Simonato C, Gioppo L, et al. (2016) Business Models for Interoperable loT Ecosystems. In International Workshop on Interoperability and Open-Source Solutions 10218 : 91-106

62. Rong K, Hu GY, Lin Y, Shi YJ, Guo L, et al. (2015) Understanding Business Ecosystem Using a 6C Framework in Internet-of-Things-Based Sectors. Int. Journal of Production Economics, 159: 41-55.

63. Dijkman RM, Sprenkels B, Peeters T, Janssen A (2015) Business models for the Internet of Things. Int. Journal of Information Management 35: 672 678.

64. Fleisch E, Weinberger M, Wortmann F (2015) Business models and the internet of things. In Interoperability and Open-Source Solutions for the Internet of Things 6-10. Springer International Publishing.

65. Hui G (2014) How the Internet of Things Changes Business Models Harvard Business Review 1-5.

66. Silva EM, Maló P (2014) loT Testbed Business Model. Advances in Internet of Things 4: 37-45.

Int J Comput Softw Eng

ISSN: 2456-4451
67. Chan HCY (2015) Internet of Things Business Models. Journal of Service Science and Management, 8: 552-568.

68. Osterwalder A, Pigneur Y (2010) Business model generation: a handbook for visionaries, game changers, and challengers. John Wiley \& Sons.

69. Bilgeri D, Wortmann F (2017) Barriers to loT Business Model Innovation.

70. Ju J, Kim MS, Ahn J H (2016) Prototyping Business Models for loT Service. Procedia Computer Science, 91: 882-890.

71. Weinberger M, Bilgeri D, Fleisch E (2016) loT business models in an industrial context. at-Automatisierungstechnik 64: 699-706.

72. Turber S, Brocke JV, Gassmann O, Flesich E (2014) Designing Business Models in the Era of Internet of Things. 9th International Conference, DESRIST 2014, Miami 17-31.

73. Westerlund M, Leminen S, Rajahonka M (2014) Designing Business Models for the Internet of Things. Technology Innovation Management Review, 4: 5-14.

74. Qin Q, Yu H (2015) Research on the Internet of Things Business Model of Telecom Operators Based on the Value NetManagement \& Engineering 21: $1838-5745$

75. Fleisch E, Weinberger M, Wortmann F (2014) Business models and the internet of things. In Bosch loT Lab White Paper.

76. Li H, Xu ZZ (2013) Research on business model of Internet of Things based on MOP. In Proceedings of the International Asia Conference on Industrial Engineering and Management Innovation. Berlin-Heidelberg, Germany: Springer.

77. Sun Y, Yan H, Lu C, Bie R, Thomas P, et al. (2012) A holistic approach to visualizing business models for the Internet of Things. Communications in Mobile Computing 1: 4

78. Leminen S, Westerlund M, Rajahonka M, Siuruainen R (2012) Towards IOT Ecosystems and Business Models. In: Andreev, S., Balandin, S. and Koucheryavy, Y., Eds., Internet of Things, Smart Spaces, and Next Generation Networking, 7469, Springer, Heidelberg, 15-26.

79. Bucherer E Uckelmann D (2011) Business models for the Internet of Things. In Architecting the internet of things (pp. 253-277). Springer Berlin Heidelberg.

80. Fan PF, Zhou GZ, (2011, September) Analysis of the business model innovation of the technology of Internet of Things in postal logistics. In Industrial Engineering and Engineering Management (IE\&EM), 2011 IEEE 18Th International Conference on (pp. 532-536). IEEE.

81. Liu L, Jia W (2010) Business model for drug supply chain based on the internet of things. 2010 2nd IEEF InternationalConference on Network Infrastructure and Digital Content 982-986.

82. Vojinović I, Barać D, Jezdović I, Labus M, Jovanović F, et al. (2017) An Approach to Designing loT-Based Business Models. In Emerging Trends and Applications of the Internet of Things (:43-70). IGI Global.

83. Zhang Y, Gregory M, Shi YJ (2007) Global engineering networks: the integrating framework and key patterns. Proc. Inst. Mech. Eng. Part B J. Eng. Manuf. 221: 1269-1283.

84. Lin Y, Zhou L, Shi Y, Ma S (2009) 3C Framework for Modular Supply Networks in the Chinese Automotive Industry. International Journal of Logistics Management 322-341.

85. lansiti M, Levien R (2004) Strategy as ecology Harvard business review 82: $68-81$ 